\title{
Enteroglucagon and Substance P-Like Immunoreactivity in Argentaffin and Argyrophil Rectal Carcinoids
}

\author{
E. Wilander ${ }^{1}{ }^{*}$, G. Portela-Gomes ${ }^{1}$, L. Grimelius ${ }^{1}$, G. Lundqvist ${ }^{2}$, \\ and V. Skoog ${ }^{3}$ \\ ${ }^{1}$ Department of Pathology, University Hospital, Uppsala, Sweden \\ ${ }^{2}$ Department of Clinical Chemistry, University Hospital, Uppsala, Sweden \\ ${ }^{3}$ Department of Surgery, University Hospital, Uppsala, Sweden
}

\begin{abstract}
Summary. A specific immunofluorescence for enteroglucagon or substance $\mathrm{P}$ or for both hormones was demonstrated in nine out of 12 examined rectal carcinoids. One tumor was argentaffin, contained ultrastructurally pleomorphic granules of the entero-chromaffin cell type, and showed immunofluorescence for substance $P$. The rest were non-argentaffin but were argyrophil with the Grimelius technique and contained round granules. The argyrophil carcinoids were immunoreactive to one or both hormones in eight cases and not fluorescent in three cases. In two of the non-argentaffin carcinoids a small number of argyrophil cells was found with the method of Sevier-Munger.
\end{abstract}

Key words: Rectum - Carcinoids - Enteroglucagon - Substance P Immunocytochemistry.

\section{Introduction}

The rectal carcinoids are regarded as "atypical" in comparison with the carcinoids of the appendix and small intestine, because as a rule they are nonargentaffin and electron microscopically contain round granules that are different from the pleomorphic granules of the enterochromaffin cell type (Williams and Sander, 1963; Black, 1968; Orloff, 1971). The presence of secretory granules would seem to suggest an endocrine function, but hitherto no hormone or polypeptide has been demonstrated in non-argentaffin rectal carcinoids. Recently enteroglucagon (Grimelius et al., 1976) and substance P (Nilsson et al., 1975; Pearse and Polak, 1975) immunofluorescence have been found in the colonic mucosa. It seemed of interest therefore to study the occurrence of these substances in rectal carcinoids. With the use of an indirect immunofluorescence

* Address for reprints: Dr. Erik Wilander, Department of Pathology, P.O. Box 553, S-751 22 Uppsala, Sweden 
technique we have examined 12 rectal carcinoids, characterized with regard to argentaffin and argyrophil reactions, for the presence of enteroglucagon and substance $P$. In addition, six of the carcinoids were examined electron microscopically.

\section{Material and Methods}

Specimens from 12 rectal carcinoids (surgically removed or biopsies) were fixed in $10 \%$ formalin, dehydrated and embedded in paraffin.

For light microscopic analysis $4 \mu \mathrm{m}$ thick sections were stained with haematoxylin-eosin and van Gieson stain and with one argentaffin (Solcia et al., 1969) and two argyrophil (Sevier-Munger, 1965; Grimelius, 1968) techniques.

For the immunocytochemical study antibodies to glucagon were raised in rabbits, by means of repeated injections of pork glucagon (Lot No. B 66 Novo Copenhagen) conjugated to bovine albumin by carbatiimide as described by Goodfriend et al. (1964). The antibodies cross-reacted with gut GLI (Novo Copenhagen), as checked in a radioimmunoassay system. Antibodies to substance $P$ were obtained in rabbits, using the same technique for conjugation of synthetic substance $P$ (Beckman, Geneva). The formalin-fixed, paraffin-embedded sections were dewaxed and placed in $0.1 \mathrm{M}$ phosphate buffered saline $\mathrm{pH} 7.4$ (PBS) for $12 \mathrm{~h}$ at room temperature, post-fixed in Bouin's fluid for $2 \mathrm{~h}$ at $37^{\circ} \mathrm{C}$ and washed in water for $1 \mathrm{~h}$. The indirect immunofluorescence method of Coons et al. (1955) was then applied, using glucagon and substance P antisera diluted $1: 20$ with PBS for the first layer and a fluorescein isothiocyanate-labelled goat anti-rabbit IgG globulin (Hyland) diluted 1:10 with PBS for the second layer. The controls used were those recommended by Goldman (1968) and included the application of antigen inactivated antisera. For the inactivation of glucagon antiserum, the antiserum was preincubated with an excess of pork pancreatic glucagon and gut GLI, respectively. The sections were examined in a Leitz Orthoplan fluorescence microscope and a standard filter setting no. 3 was used. Photographs were taken with Kodak Tri-X pan film.

Small pieces of six tumors (about $1 \mathrm{~mm}^{3}$ ) were cut out of the paraffin blocks for electron microscopic examination. They were deparaffinized in xylol, dehydrated in absolute alcohol and embedded in Epon 812. After localization of the desired tumor tissue in approximately $1 \mathrm{\mu m}$ thick toluidine blue stained sections, ultrathin sections were prepared with an LKB Ultrotome, contrasted with uranyl acetate and lead citrate, and viewed in a Zeiss EM 9 electron microscope at $60 \mathrm{~kW}$.

\section{Results}

In routinely stained sections the rectal carcinoids were typical in all cases and consisted of fairly uniform cells, which were arranged in anastomosing cords, tubular structures or ribbon-like formations. In most tumors a mixture of the different patterns was seen. The tumor cells were surrounded by a relatively prominent fibrous stroma.

The Argentaffin and Argyrophil Reactions. As seen in Table 1, only one tumor was argentaffin (Fig. 1). The rest of the tumors were argyrophil with the Grimelius technique (Fig. 2), although the reaction was weak in some cases. In two of the non-argentaffin carcinoids a small number of cells that were argyrophil with the Sevier-Munger technique were also found (Fig. 3). 
Table 1. Enteroglucagon and substance P-like immunoreactivity in 12 argentaffin and argyrophil rectal carcinoids

\begin{tabular}{|c|c|c|c|c|}
\hline & \multirow{2}{*}{$\begin{array}{l}\text { Number } \\
\text { of } \\
\text { tumors }\end{array}$} & \multirow{2}{*}{$\begin{array}{l}\text { Argentaffin } \\
\text { tumors }\end{array}$} & \multicolumn{2}{|c|}{ Argyrophil tumors } \\
\hline & & & $\begin{array}{l}\text { Sevier-Munger } \\
\text { technique }\end{array}$ & $\begin{array}{l}\text { Grimelius } \\
\text { technique }\end{array}$ \\
\hline $\begin{array}{l}\text { Enteroglucagon } \\
\text { Immunofluorescence only }\end{array}$ & 2 & 0 & 1 & 2 \\
\hline $\begin{array}{l}\text { Substance P } \\
\text { Immunofluorescence only }\end{array}$ & 1 & 1 & 1 & 1 \\
\hline $\begin{array}{l}\text { Enteroglucagon }+ \text { Substance } P \\
\text { Immunofluorescence }\end{array}$ & 6 & & (1) & 6 \\
\hline Non-fluorescent tumors & 3 & 0 & 0 & 3 \\
\hline
\end{tabular}

() indicates a small number of argyrophil cells

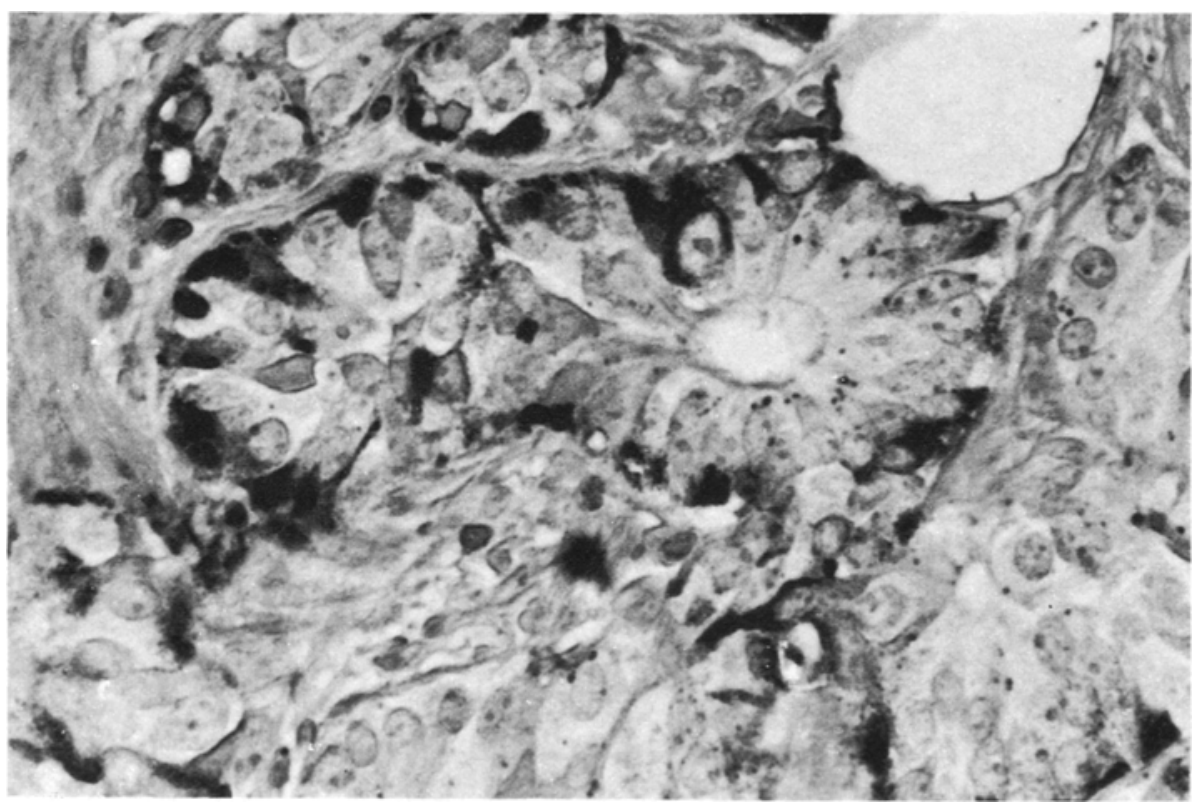

Fig. 1. The argentaffin rectal carcinoid, with relatively marked silver granulation in the cytoplasm of many tumor cells. $\times 800$

Immunocytochemistry. With the indirect immunofluorescence method enteroglucagon was present in two tumors, substance $\mathrm{P}$ in one tumor and both enteroglucagon and substance $P$ in six tumors (Figs. 4-5). Three carcinoids were nonfluorescent. The tumor showing only substance $P$ immunofluorescence was argentaffin. No obvious relationship was found between the Sevier-Munger 


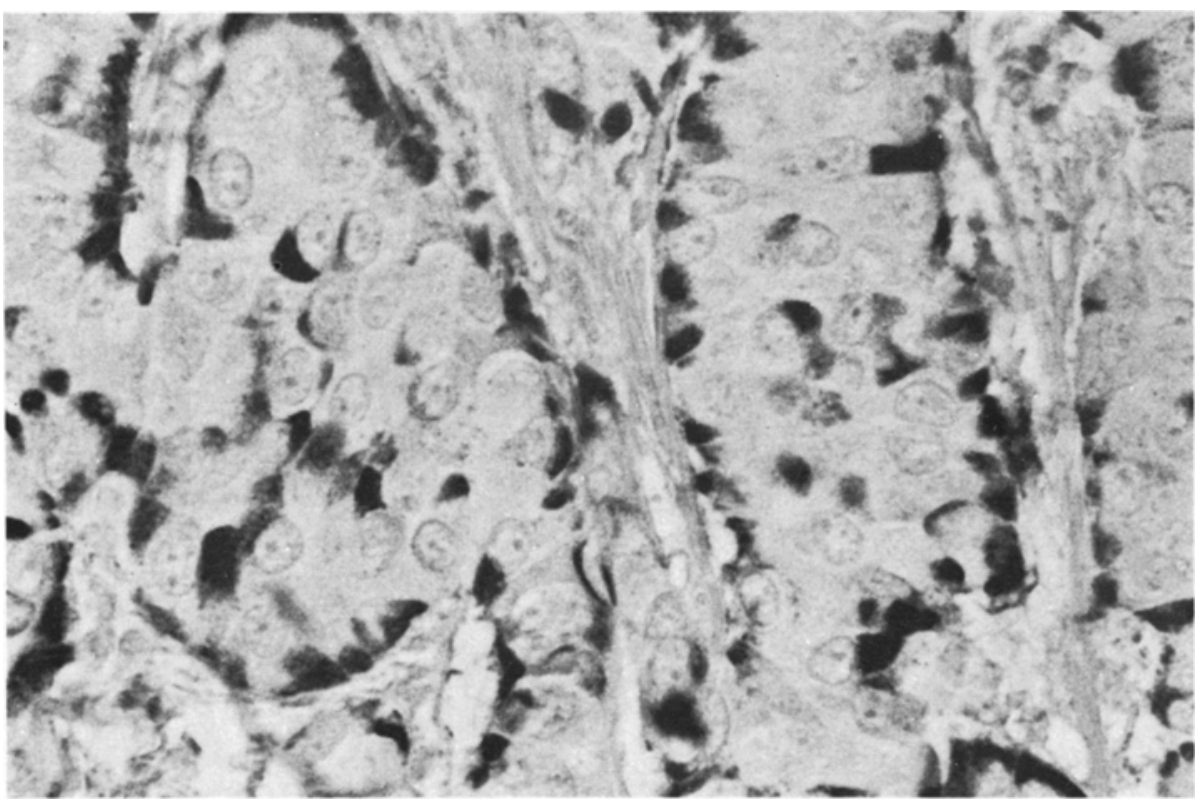

Fig. 2. A rectal carcinoid with silver granulation in most tumor cells. Grimelius technique. $\times 800$

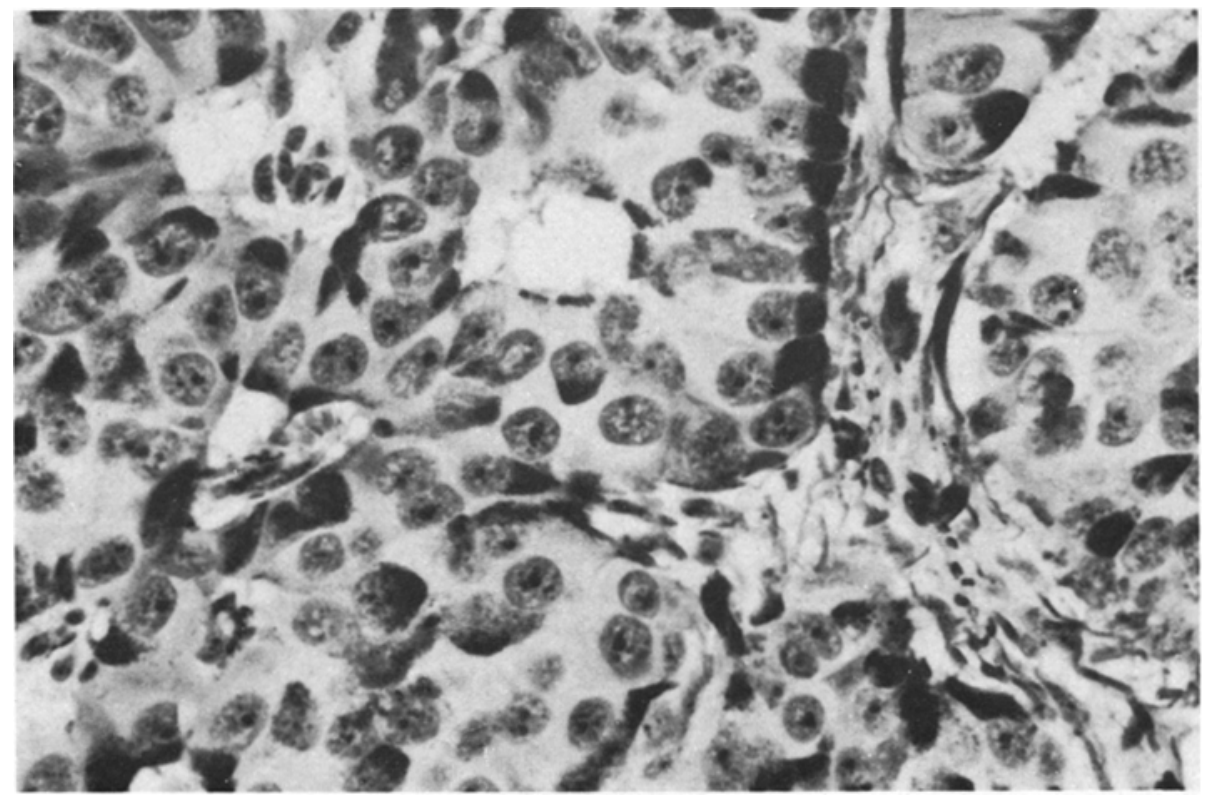

Fig. 3. The same tumor as in Figure 2, with scattered silver granulated tumor cells. Sevier-Munger technique. $\times 800$ 


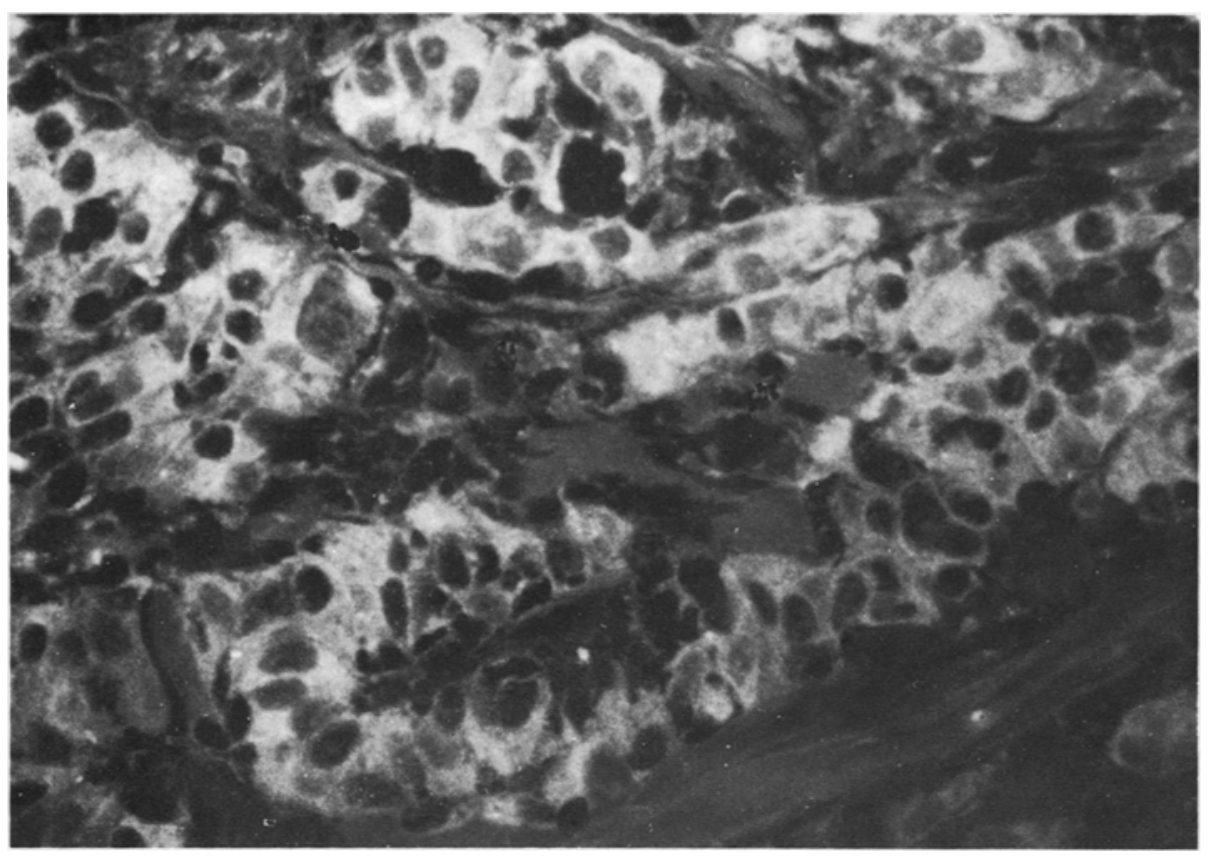

Fig. 4. A rectal carcinoid showing specific immunofluorescence for enteroglucagon in most tumor cells. $\times 800$

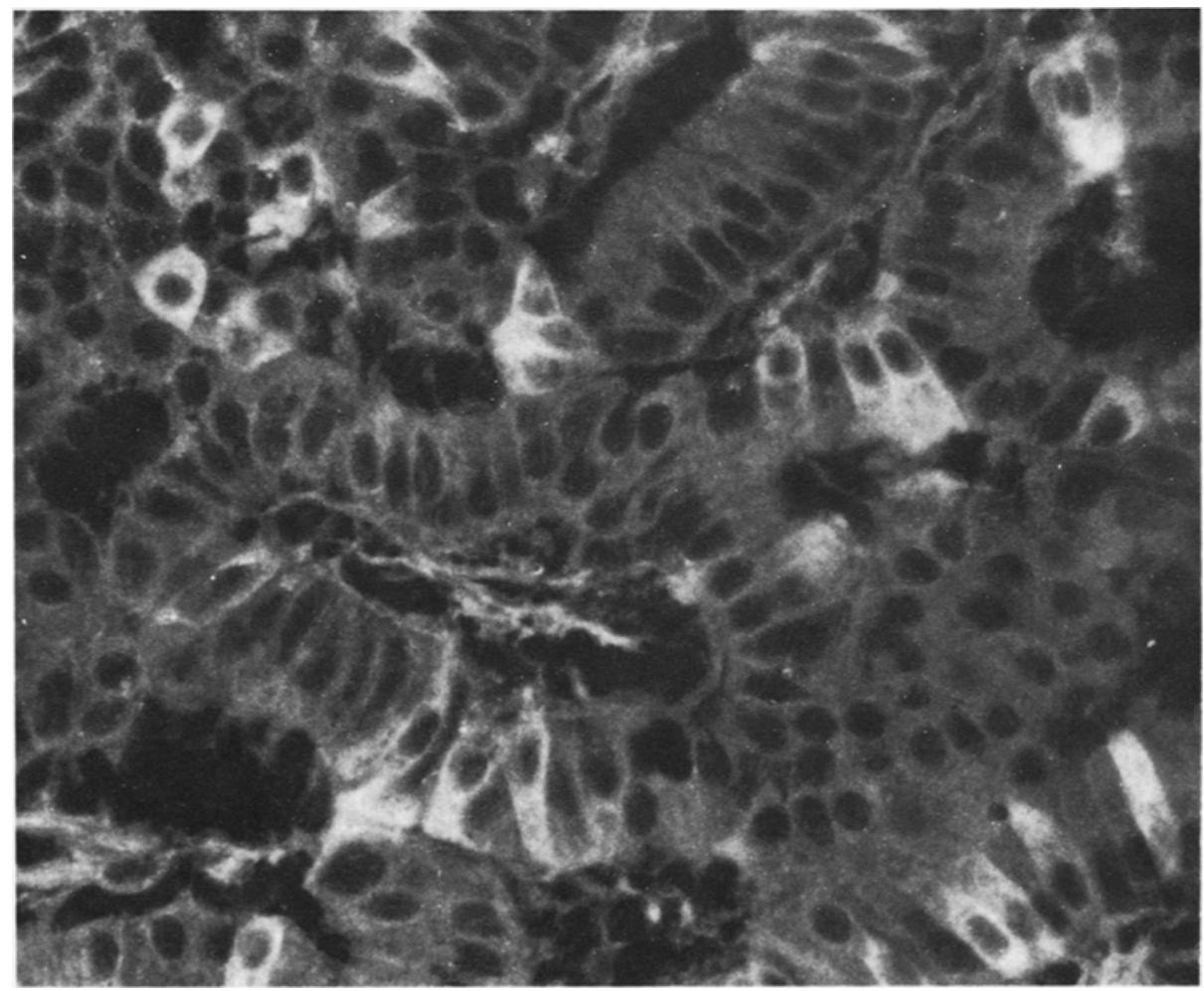

Fig. 5. A rectal carcinoid showing specific substance $P$ immunofluorescence in scattered tumor cells. $\times 800$ 


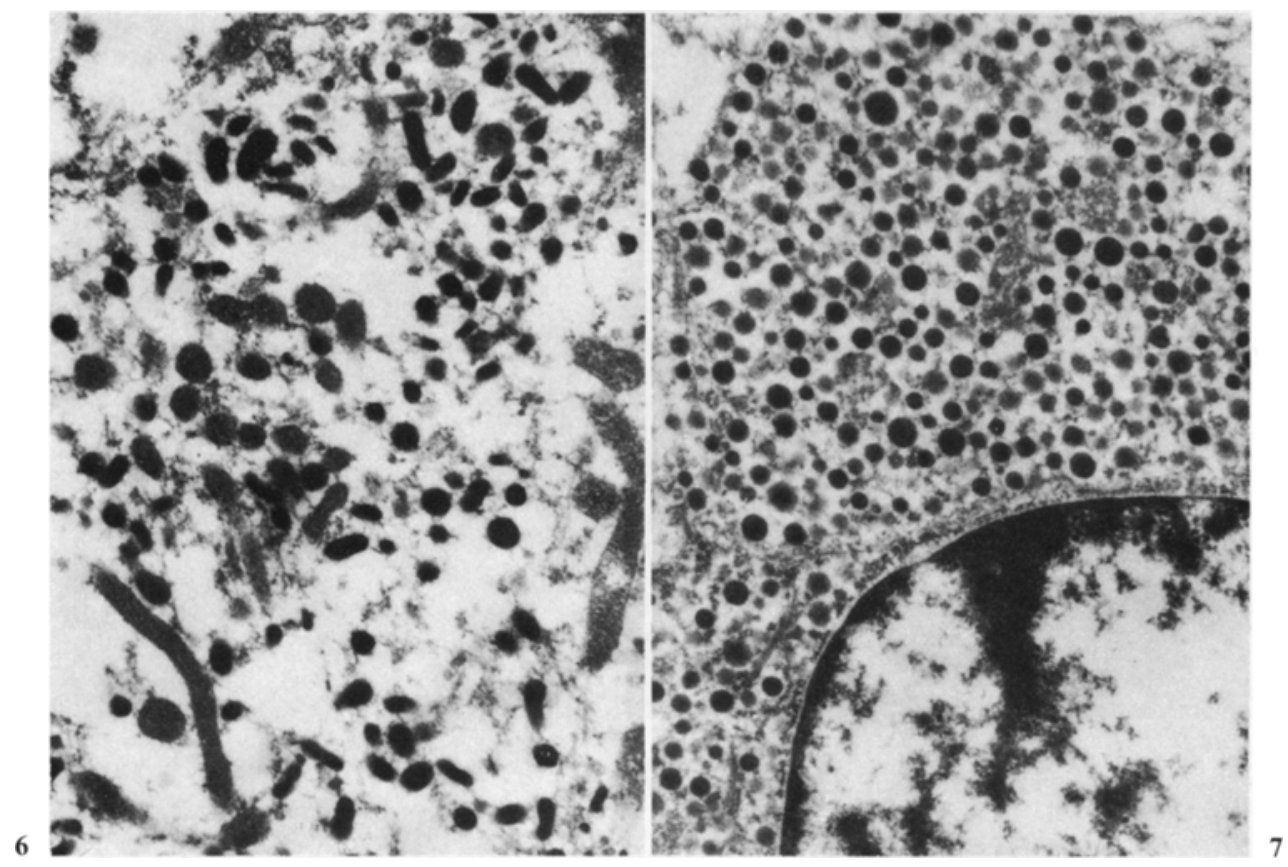

Fig. 6. Electron micrograph of the argentaffin rectal carcinoid (see Fig. 1). Pleomorphic granules are seen. $\times 15,300$

Fig. 7. Electron micrograph of an non-argentaffin but argyrophil (Grimelius technique) rectal carcinoid. The secretory granules are round and show slight variations in size and electron density. $\times 15,300)$

argyrophil reaction and the results of the immunocytochemical study. The frequency of fluorescent cells varied considerably in different tumors.

Electron Microscopy. The argentaffin tumor contained pleomorphic granules (Fig. 6) similar to those found in the enterochromaffin cells. In the non-argentaffin but argyrophil carcinoids the secretory granules were round, with minor variations in size and electron density (Fig. 7).

Although both enteroglucagon and substance $P$ were present in six tumors, several types of secretory granules were not observed in any tumor.

\section{Discussion}

One of the examined rectal carcinoids was argentaffin and contained pleomorphic granules similar to those of the enterochromaffin cells. It is probable that this tumor secreted serotonin. However, it also exhibited a specific immunofluorescence for substance P. Recently the enterochromaffin cells of the gastrointestinal mucosa have been shown to contain either motilin (Pearse et al., 1974) or substance P (Nilsson et al., 1975; Pearse and Polak, 1975; Heitz et al., 1976). 
In addition, substance $\mathrm{P}$ has been demonstrated in argentaffin carcinoids of the small intestine (Alumets et al., 1977; Håkansson et al., 1977).

Six of the argyrophil rectal carcinoids displayed specific immunofluorescence for both enteroglucagon and substance P. That endocrine tumors can produce several hormones has been demonstrated previously (Larsson et al., 1975). Although the chemistry of the argyrophil reaction is unknown, ultrastructural studies have shown that the silver granulation is associated with the endocrine secretory granules storing polypeptide hormones (Grimelius, 1969; Vassallo et al., 1871; Grimelius and Strand, 1974) or biogeneic amines (Håkansson et al., 1971). Since three of the argyrophil carcinoids were non-fluorescent, it is probable that additional hormones occur in the rectal carcinoids.

It may be of interest to note that substance $P$ immunofluorescence was observed in non-argentaffin carcinoids, which indicates that this substance can be produced in non-enterochromaffin endocrine cells or that the tumor cell of carcinoids have the potential to differentiate in several directions, with hormone production different from that of normal endocrine cells as the result.

Acknowledgement. Thanks are due to Professor Sture Falkmer, Professor Unne Stenram and Dr Lars-Bertil Schnürer for contributing in the collection of the material. The skilful technical assistance of Ann-Charlotte Hallner and Lena Rönning is appreciated. The work was carried out with the aid of grants from the Medical Research Council (Project Nr. 102, 4777 and 4534).

\section{References}

Alumets, J., Håkansson, R., Ingemansson, S., Sundler, F.: Substance P and 5-HT in granules isolated from an intestinal argentaffin carcinoid. Histochemistry (in press, 1977)

Black, W.: Enterochromaffin cell types and corresponding carcinoid tumours. Lab. Invest. 19, 473-486 (1968)

Coons, A.H., Leduc, E.H., Connolly, J.M.: Studies on antibody production. I: A method for the histochemical demonstration of specific antibody and its application to a study of the hyperimmune rabbit. J. Exp. Med. 102, 49-60 (1955)

Goldman, M. : Fluorescent antibody methods. New York: Academic Press 1968

Goodfriend, T.L., Levine, L., Fasmann, G.D.: Antibodies to bradykinin and angiotensin. A use of carbatiimides in immunology. Science 144, 1344-1346 (1964)

Grimelius, L. : A silver nitrate stain for $\alpha_{2}$-cells in human pancreatic islets. Acta Soc. Med. Upsaliensis 73, 343-276 (1968)

Grimelius, L.: An electron microscopic study of silver stained adult human pancreatic islet cells, with reference to a new silver nitrate procedure. Acta Soc. Med. Upsaliensis 74, 28-48 (1969)

Grimelius, L., Capella, C., Buffa, R., Polak, J.M., Pearse, A.G.E., Solcia, E.: Cytochemical and ultrastructural differentiation of enteroglucagon and pancreatic type glucagon cells of the gastrointestinal tract. Virchows Arch. B Cell Path. 20, 217-228 (1976)

Grimelius, L., Strand, A.: Ultrastructural studies of the argyrophil reaction in $\alpha_{1}$-cells in human pancreatic islets. Virchows Arch. A Path. Anat. Histol. 364, 129-135 (1974)

Heitz, Ph., Polak, J.M., Timson, C.M., Pearse, A.G.E.: Enterochromaffin cells as the endocrine source of gastrointestinal substance P. Histochemistry 49, 343-347 (1976)

Håkansson, R., Bergmark, S., Brodin, E., Ingemansson, S., Larsson, L.-I., Nilsson, G., Sundler, F.: Substance P-like immunoreactivity in intestinal carcinoid tumors: Substance P, U.S. von Euler and B. Pernow, Eds., New York: Raven Press 1977

Håkansson, R., Owman, Ch., Sporring, B., Sundler, F.: Electronmicroscopic classification of amineproducing endocrine cells by selective staining for ultra-thin sections. Histochemie 27, 226-242 (1971)

Larsson, L.-I., Grimelius, L., Håkansson, R., Rehfeld, J.F., Stadil, F., Holst, J., Angervall, L., 
Sundler, F.: Mixed endocrine pancreatic tumors producing several peptide hormones. Am. J. Path. 79, 271-280 (1975)

Nilsson, G., Larsson, L.-I., Håkansson, R., Brodin, E., Pernow, B., Sundler, F.: Localization of substance P-like immunoreactivity in mouse gut. Histochemistry 43, 97-99 (1975)

Orloff, M.J. : Carcinoid tumors of the rectum. Cancer 28, 175-180 (1971)

Pearse, A.G.E., Polak, J.M.: Immuno-cytochemical localizationn of substance P in mammalian intestine. Histochemistry 41, 373-375 (1975)

Pearse, A.G.E., Polak, J.M., Bloom, S.R., Adams, C., Dryburgh, J.R., Brown, J.C.: Enterochromaffin cells of the mammalian small intestine as the source of motilin. Virchows Arch. B Cell Path. 16, 111-120 (1974)

Solcia, E., Sampietro, R., Capella, C.: Differential staining of catecholamines, 5-hydroxytryptamine and related compounds in aldehyde-fixed tissues. Histochemie 17, 273-283 (1969)

Sevier, A., Munger, B.: A silver method for paraffin sections of neural tissue. J. Neuropath. exp. Neurol. 24, 130-135 (1965)

Vassallo, G., Capella, C., Solcia, E.: Grimelius' silver nitrate stain for endocrine cell granules, as shown by electron-microscopy. Stain Technol. 46, 7-13 (1971)

Williams, E.D., Sandler, M.: The classification of carcinoid tumours. Lancet 1963 I, 238-239

Received May 18, 1977 